Fernanda R. Rosa ${ }^{1}$

\title{
MADE IN BRAZIL: CONSPIRACY THEORY AND THE FLOW OF INFORMATION IN ONE-TO-ONE WHATSAPP CONVERSATIONS
}

\author{
FEITO NO BRASIL: TEORIA DA CONSPIRAÇÃO E FLUXO DE INFORMAÇÃO EM \\ CONVERSAS UM-A-UM NO WHATSAPP
}

\begin{abstract}
This article aims to shed light on the multiple and complex ways that information flows in communication processes mediated by digital platforms. Based on actor-network theory, it unveils the dynamics that occurred in one-to-one conversations on WhatsApp, regarding the controversial death of the Brazilian Supreme Court Justice, Teori Zavascki, in 2017. Analyzing primary data from conversations in which the author was part, the paper discusses the signs of authority that allow for non-verified and fictional articles to circulate as if they were news pieces, enabling conspiracy theories to take shape. The paper defends that mutual responsibility in building the narrative with members of likeminded groups, and "translation" processes, in which the sender and information merge their characteristics to forge trust, are important factors to understand the circulation of content in private messaging applications. It addresses the role of digital platforms in the diffusion of conspiracy theories and in how "fake news" is framed as part of a distributed communication process where co-responsibility can be observed. The paper argues that the opposition between "real" and "fake" is too limited to make sense of a how conspiracy theories spread digitally, given that such terms do not account for the technopolitics of the phenomenon.
\end{abstract}

Keywords: Fake news. Conspiracy theory. WhatsApp. Actor-network theory. Interpersonal communication.

1 Center for Advanced Research in Global Communication (CARGC), Annenberg School for Communication, University of Pennsylvania. E-mail: fernandarosa@riseup.net. 


\section{Resumo}

Este artigo visa lançar luz sobre as múltiplas e complexas formas em que a informação flui nos processos de comunicação mediados por plataformas digitais. Com base na teoria ator-rede, ele desvela a dinâmica de conversas um-a-um ocorridas no aplicativo de mensagens instantâneas WhatsApp a respeito da polêmica morte do juiz do Supremo Tribunal Federal, Teori Zavascki, em 2017. Analisando dados primários de conversas das quais a autora fez parte, $o$ artigo discute os sinais de autoridade que permitem que artigos não-verificados e fictícios circulem como se fossem notícias, possibilitando que as teorias conspiratórias tomem forma. Este artigo defende que a responsabilidade mútua na construção de narrativas a partir da colaboração de membros de grupos de pessoas com pensamentos semelhantes e os processos de "tradução" - em que remetente e informação fundem suas características para forjar confiança - são fatores importantes para entender a circulação de conteúdo em aplicativos de mensagens privadas. $O$ artigo aborda o papel das plataformas digitais na difusão de teorias da conspiração e no enquadramento das "notícias falsas" como parte desse processo de comunicação distribuída onde há corresponsabilidade, mostrando que a oposição entre "real" e "falso" é muito limitada para dar sentido a como as teorias da conspiração se espalham digitalmente, visto que tais termos não dão conta da tecnopolítica do fenômeno.

Palavras-chave: Fake news. Teoria da conspiração. WhatsApp. Teoria ator-rede. Comunicação interpessoal.

\section{INTRODUCTION}

ON A RAINY AFTERNOON from the distant past last December, I climbed the steps of a gallery in São Paulo downtown to find Mother Aleksandra behind a door without identification or bell. She greeted me promptly with a purificatory bath and a secret salute, something of Templars, Freemasonry and Anonymous Legion. Under a cloud of incense and the ecumenical gaze of saints from different continents of the Earth and beyond, the seer, who advises Brasília offices [Brazilian capital] and mansions in Jardins, revealed their predictions for 2017 exclusively for The Intercept Brasil. (CUENCA, 2017) ${ }^{2}$

This story was published on January 5, 2017 by the Brazilian chapter of The Intercept, a media outlet co-founded by Glenn Greenwald, a Pulitzer Prize winning journalist. The columnist who wrote the story, J. P. Cuencas, continued, "I transcribe below ipsis litteris the striking passages of the conversation - taking no responsibility for the seer's words." The predictions included the fall of Trump in 2018, changes in national politics and a death. There is a death

2 This and other excerpts from Brazilian outlets were translated by the author. 
that will help untie those knots and unlock the board. A big name of Brazilian politics will be assassinated by the end of the year. That will solve almost everything."

I was sent this piece on January 19, 2017. On that day, newspapers carried the sad and astonishing story about a small plane crash in the state of Rio de Janeiro, and the death of the Supreme Court Justice Teori Zavascki, who was vacationing. Zavascki was an important name in Brazilian politics at that moment because he was in charge of the Car Wash judicial inquiry, the most prominent operation in the country investigating bribery cases at the state oil company Petrobrás involving more than a hundred politicians and entrepreneurs. A week before, his name was in the news referring to the diligence and hard work of his team in analyzing that month more than eight hundred testimonies that mentioned important names in Brazilian politics, including the then president, Michel Temer. (BRIGIDO, 2017) Skepticism about the crash being an ordinary accident arose quickly.

The Guardian reported that "the timing [of the accident] prompted speculation that the judge had fallen victim to foul play", followed by a balancing quotation from a political watchdog representative saying that it was "too premature to say what happened". (WATTS, 2017) Two days after the accident, in Folha de São Paulo, a major Brazilian newspaper, a columnist titled their article "It is not conspiracy theory, it is doubt". (GASPARI, 2017) They were responding to the seesaw of narratives between established media outlets and tweets, Facebook posts and other sources. For instance, the title of an article in Folha the night of the accident said, "Death of Teori Zavascki feeds conspiracy theories". (BALLOUSSIER, 2017) The quotations, in this case, were tweets from celebrities, including from a singer who opined that "They erased Teori [Zavascki]".

At a time when constraints to publish and share information have diminished significantly (SHIRKY, 2008), the dynamic among people connected through social media platforms which allow one-to-one and one-to-many communications gains relevance. Social media users are able to build frames of analysis (SCHEUFELE, 1999), that the traditional media can oppose or resonate based on what is considered legitimate evidence. Ideally, journalism is understood as an instrument to inform public opinion, which supposes a "reasoning public" and is different from "mere opinions". (HABERMAS, 1974, p. 50) The journalism idealized as a mediator in public sphere is not a "mere organ for the spreading of news". Instead, it is a "mediator and intensifier of public discussion". (HABERMAS, 1974, p. 53) Thus, normatively, journalistic news carries a different stature in comparison with common guesses or rumors. In practice, 
though, what journalism and news are - whether one's opinion in a blog, news with non-verifiable sources, or public opinion - will depend on reception and how messages are decoded. (HALL, 2006) As James Carey points out, "news is not information but drama. It does not describe the world but portrays an arena of dramatic forces and action; it exists solely in historical time; and it invites our participation on the basis of our assuming, often vicariously, social roles within it". (CAREY, 2009, p. 17)

One of the main contributions of actor-network theory (ANT) is to provide a rationale and a methodological approach to help explain social dynamics (LATOUR, 2005), unveiling the drama, to use Careys's word, so to speak. In light of the phenomenon of "problematic information" (JACK, 2017), more commonly referred to as "fake news," and the consequent processes of disinformation and misinformation in operation, the goal of this paper is to shed light on the multiple and complex ways that information flows - and gains plausibility through the dynamic of sharing - among individuals and digital platforms. It is focused on understanding the pathways (LATOUR, 2008) of the conspiracy theory about the death of the Justice Teori Zavascki in one-to-one WhatsApp conversations in which the author was part. As I aim to establish, "fake news", or problematic information, the term that will be adopted here, are intertwined with people's goals and digital technologies' functions, and thrives within the network of relations that this enables.

As already shown, news has a strong socialization component in that our peers' posts and messages on social media have become primary sources for news consultation. (CLARK; MARCHI, 2017; HOWARD, 2020) "News is the information you need to have some engaging conversations with someone," says a twenty-year-old in a long-term study with the young population in the United States. As the authors of this study suggest, among this social group, news "always comes [...] in the form of an informal invitation to conversation, suggested by a friend or acquaintance through a social media site". (CLARK; MARCHI, 2017, p. 79)

Yet, on the centrality of digital platforms, research has shown that the dissemination of problematic information is not dissociated from the capabilities of reach, functioning and the commercial aspects of social media applications. (EMPOLI, 2019; HOWARD, 2020) The affordances of digital platforms, or what they allow someone to do, as we shall see, impact the circulation of information online and how interpretations take form. As Bruno Latour puts it, "When people say of technologies that they are neither good nor bad, they forget to add: nor neutral". (LATOUR, 2013, p. 219) In this way, materiality, rep- 
resented here by social media applications, is a fundamental dimension of the actor-network of problematic information.

In this sense, people, news-or any sort of content - and digital platforms are here considered actors. Regarding this, it is important to understand that actor-network theory authors assume not only a symmetric relation between humans and non-humans, society and technological artifacts, but also understand that there is a continuous interchange between human goals and technological functions. This happens in such a way that a speed bump, for instance, can be understood as a "delegation" of engineers' goals in pavement and concrete, and a "translation" of the speed law enforcement into a technique. In other words, the desired action of making drivers slow down is, in this case, not only expressed by a "negotiable" speed limit sign, in which the driver has the opportunity to ignore it; it is in fact compelled by "nonnegotiable speed bumps". (LATOUR, 1999, p. 186-188) Thus, by mediating humans' goals, the technique influences human behavior with its own functions and characteristics.

It is the recognition that artifacts assume actions that make them actors or actants, opening a window to investigate their characteristics as such. For Latour, "Responsibility for action must be shared among the various actants" (LATOUR, 1999, p. 180) because action is conceived not as an exclusive attribute of humans, but as a distributed action, a result of a combination of agents, including technical artifacts. Because of that, "When we act, we must ask: who else acts at the same time as us? How many entities do we invoke? [...]". (BRUNO, 2012, p. 696, own translation) These tenets guide the analysis that follows.

\section{THE PATHWAYS OF INFORMATION AND INTERPRETATIONS}

I received the Mother Aleksandra predictions on the day of the justice's death. Alicia ${ }^{3}$ sent it to me through a one-to-one conversation via WhatsApp, asking, "Have you read this?" Days after, I decided to try to understand the context in which she decided to share that article. Her reporting is revealing. She had read the piece some weeks before on Facebook and had not shared it with anyone until the justice's death. She follows the author of the article, who is an award-winning chronicler recognized with international prizes. On the day of the accident, his post appeared on her timeline again. She then sent it to some friends, with whom she shares political views, and to people that "flirt with both sides" in politics, which means, are not completely opposed to her mindset.

3 The names were changed. 
The group polarization implied in her story is important for our arguments and for understanding the next steps along the information pathways. In August 2016 the elected president Dilma Rousseff, from the leftist Workers Party (PT), was impeached based on allegations of creative accounting and the editing of a decree to use supplementary credit, which had not been given congress' approval. (BRASIL, 2016) Her vice, Michel Temer, from a centrist party, the Brazilian Democratic Movement Party (PMDB), supported her fall, and became the next president. Following his inauguration, Temer implemented a right leaning economic agenda guided by austerity proposals, ${ }^{4}$ drastically changing the government direction (PHILLIPS, 2016).

One can find pro- and against-impeachment opinions among the population that form two main sides. On the one side, the pro-impeachment rationale frames the Workers Party as a gang ("quadrilha"), a group of corrupt politicians who use political power for their own benefit. Car Wash Operation, for its broad media visibility, and for investigating numerous Workers Party's partisans, was used as the main evidence of that rationale. On the other side, arguments against the impeachment frame the whole impeachment process as it occurred as "a coup d'etat". Among the facts that sustain this narrative is the leak of the conversation of a senator, a key ally of the president Temer, suggesting that stopping the investigation of corruption was necessary to take Rousseff out of office and to install Temer instead. In the same tape, the name of the justice Teori Zavascki, who died in the plane accident, was mentioned by Temer's ally as someone "closed off' to making deals". (GREENWALD, 2017) Justice Zavascki was appointed by Rousseff, the impeached president, and due to his death, Temer, the vice-president who took power after Rousseff was ousted, was supposed to appoint a new justice, which has leveraged questions about conflict of interest, since he is personally cited in the Car Wash accusations that were under Justice Zavascki's analysis. (COLON, 2016; PIVA, 2017)

Under this context, the scenario is set for many people to doubt the nature of the plane crash, but clearly, people that consider the impeachment a coup, have even more reasons to take speculations into consideration. As explained by Sunstein (2001), in likeminded group discussions, "people are likely to move toward a more extreme point in the direction to which they were previously inclined". This leads to the phenomenon of "cascades", when groups move toward a certain set of beliefs or actions which are commonly "driven by information". (SUSTEIN, 2001) That was one of the reasons for me to receive that chronicle

4 For more information on this historical moment, Cf. the Oscar-nominee documentary "The edge of democracy". (THE EDGE..., 2019) 
piece then; I was considered an equal, who to some extent shared the beliefs that would lead to the interpretation of an unsolved death as an assassination.

The discursive architecture where users express their opinions and thoughts (FREELON, 2015), used to create these in-group conversations, is relevant in this context. WhatsApp is Facebook's private messaging application designed for mobile phones, and connected to the user's phone number, which allows the exchange of encrypted messages and some level of control by the sender through her audience by contrast to Facebook's news feed. In regard to this, Alicia explained to me why she did not share the Mother Aleksandra's post on Facebook: "There, I expose myself, I can have problems, my boss can see".

I argue that here, her motivation to exchange private messages through WhatsApp regarding the prediction of a murder on the day of the accident shows an example of communitarianism, in which "the maintenance of ingroup/outgroup borders" (FREELON, 2015, p. 777) and the creation of a safe place with people who have similar beliefs are key. At the same time, her privacy protection is also at stake, along with the feeling that her media preferences should flow appropriately, among friends who do not include her boss. In other words, they should flow according to informational norms determined by some actors, type of information, and constraints, as the theory of privacy as contextual integrity points out. (NISSENBAUM, 2010)

Additionally, what Alicia's behavior suggests is an interesting interaction with Facebook's algorithms of relevance and the use of information. She shared the post only when it appeared for the second time, and opted for private chats to do so. What is important to remember, though, is that in using WhatsApp her action is still supported by a Facebook company, a fact that has implications when considering the traces that digital communication leaves by default (BRUNO, 2012). While Alicia opted for one application over another, following her privacy preferences, her communication traces are still under Facebook ownership and governance. For instance, one of the company's recent patents aims at quantifying the level of its users' influence by analyzing their online interaction with other users. (MACHADO, 2018) In other words, in technopolitical terms, her communication traces can be subject to analysis, handling, and monetization.

After receiving the Mother Aleksandra chronicle from Alicia, I shared it with two other friends in one-to-one conversations through WhatsApp. Interestingly, both sent me another article in reply with the title "Urgent: Federal Police finds that plane in which minister Teori Zavascki boarded was being followed for 16 days" (own translation). The news came from a website called 
"Diário do Brasil" (Diary of Brazil), which I had never heard of until then, but whose name could be easily confused with historical and traditional newspapers, though, such as "Jornal do Brasil", and other outlets that have "diário" (diary) in the name. The piece was short:

The scoop is from journalist Cláudio Tognolli, Yahoo.

Federal Police want to know who accessed the photo of the plane that killed Teori [Zavascki] in the Beechcraft database. According to information, the record containing data and the image of the aircraft was accessed almost 1,900 times in a single day. Someone has been after this data since January 3. Note below in the airplane prefix". (CARVALHO, 2017)

Figure 1 - Picture reproduced from Diário do Brasil

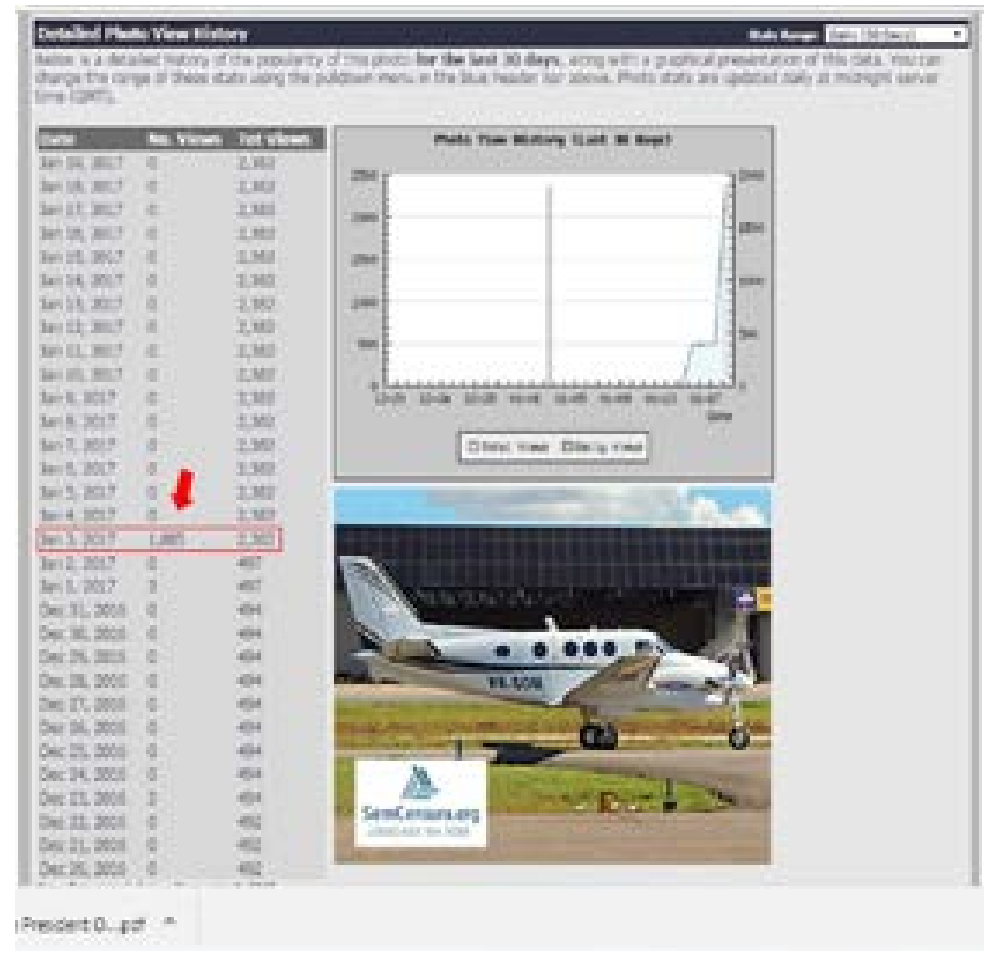

Source: Reproduced from PAND (2016). 
The small article is surrounded by advertisements, that included a big aviation company and a link to the Facebook's Diário do Brasil profile, with more than 230 thousand followers as of January 2017. In the bottom, there is also a link to the supposed airplane's picture on a database (PAND, 2016), although it was not easy to find it with so many stimuli on the webpage. On the date that the article was released, the picture had more than twenty-one thousand accesses, according to the link counter, decreased to more than five thousand and four thousand in the following days. A search on a search engine like Google showed that many other small sites replicated the article.

Sophia and Rachel, who sent this article to me and with whom I share political views, had leading positions at the organizations where they worked. I asked both how they had access to that link. Their replies were telling. Sophia explained that she heard about the article during an in-person conversation with a colleague with whom she was speculating about reasons for the suspicious death of Teori Zavascki. Sophia, then, searched on Facebook for more information, and found many links, among which she selected the one in Diário do Brasil for recognizing it as a source that circulates in a community that she is part of on Facebook called "People Against the Coup Forum" (own translation). This was the sign of authority for her to share it with me, upon receiving the Mother Aleksandra piece that I sent her. While Sophia only shared the Diário do Brasil link once, she talked in person about its content with other friends, "helping them complete the list of speculations and conspiracies" when discussing the justice's death in informal conversations at her workplace. Facebook, Google, and WhatsApp can be considered participants in such in-person conversations as well, although their presence is not self-evident.

Unlike Sophia, Rachel did not access the Diário do Brasil article via an active search, but through "a friend who is connected and smart" with whom she commonly talks about politics. Her explanation about this person shows that, in this case, her colleague himself was the main sign of authority for the piece: "I always take what he shares with me into consideration". During a conversation, Rachel inquired of her friend why he thought that the plane was "being followed" before the accident. He, then, sent her the Diário do Brasil link through WhatsApp. She said that when looking at the website, she did not pay attention to the whole page, but focused on the chart that shows the number of accesses to the plane picture on January 3, which the site framed with a red rectangle. After that, she searched for the information on Google to see if other familiar sources and blogs had posted about it, but the answer was negative. "I believe in the idea that it was not an accident", she admitted, justifying why she 
searched for other sources. Above all, she would like to confirm that idea. After receiving the Mother Alecksandra piece, she noted that she saw an opportunity to share the link with someone who could "canvass" it - me. She just sent the link, without any comment about what my mission would be upon receiving it.

\section{BEYOND THE OPPOSITION BETWEEN “FAKE” AND “REAL”}

Based on these pathways, I argue that the level of trust that Sophia and Rachel had in the Diário do Brasil article, with the plane's picture and speculative information, is comparable to that put in the Mother Aleksandra chronicle, a literary genre that gained another "mode of existence" (LATOUR, 2013) in the face of its political context. When they shared the Diário do Brasil piece with a shallow checking, it functioned as an uncommitted "have you seen this?", a call to continue the conversation. There was no certainty about how reliable the article is, but that was not the most important driver for that communication to happen. Instead, some sort of authority recognized before sharing (a friend or a Facebook group), and mutual responsibility in building the narrative with me, the receiver, within a likeminded group were crucial.

With regard to the chronicle, it led to different interpretations but convergent ends. While Rachel first believed that Mother Aleksandra exists and is possibly a virtuous seer, Sophia put more emphasis on the fact that the Intercept's columnist is a chronicler. In this case, his predictions would not be necessarily based on a seer's gift, but on "elements of gossip, and 'backstage conversations' that can allow him to predict the future". Sophia and Rachel have no certainties, other than the idea of a politically motivated murder that relates to their beliefs.

Some consequences arise from this. First, this can be an alternative starting point for future studies on the use of news from non-verifiable sources. Different from a lack of information literacy (ROSA; DIAS, 2021) - a reasonable motive for people to share problematic information-likeminded group conversation dynamics make other motivations explicit. In communitarian communication, specifically, there seem to exist implicit norms regarding the co-responsibility for the shared content, and the content tends to move the group in directions that its members have greater predisposition to follow. This evidence also goes beyond the common logic of intentionality/non-intentionality in misleading communication, which appear as the basis for definitions of disinformation and misinformation, respectively. (JACK, 2017) Rather, it is the 
trust implied by likemindedness and privacy platforms that provides the rationale for sharing information. The discursive architecture of private messaging applications (e.g. WhatsApp) is constitutive of these dynamics, especially in extreme contexts of balkanization (SUSTEIN, 2001), as the one studied here, where security and some synergy between the parties are necessary for uncommitted communication to happen.

Second, in the absence of an established or conventional media outlet, the authority of the news can be substantiated by who is sharing it. At this moment, one notices a process of "translation" between both the news and the person, or, in other words, "the creation of a link that did not exist before and that to some degree modifies the original two [constituents]". (LATOUR, 1999, p. 179) With that, the sense of friendship and trust between people give them license to exchange unverified information. This can be studied in the future as a fundamental characteristic of individuals as media outlets and horizontal influencers as part of a sociotechnical arrangement entangled with other artifacts in an actor-network.

Third, the similar uncertainties present in the consideration of a unverified news source and a story from a well-known chronicler who correctly "predicted" a death, elicit questions about what "fake news" means. When analyzing the property of being fictional, Bruno Latour remembers that fiction is not opposed to reality, but a version of it. For instance, a fictional artifact, such as a piece of art, exists in relation to the imagination of the audience, which the art itself contributes to foster. Without imagination, a piece of art may be seen as just a conglomerate of raw materials, diluting its artistic sense. In Latour's words, "If we call the beings of fiction fictive or fictional, it is not because they are false, unreliable, or imaginary; it is, on the contrary, because they ask so very much from us and from those to whom we have the obligation to pass them along so they can prolong their existence". (LATOUR, 2013, p. 249) This is applicable to the chronicle, as it has populated the readers' imagination and gained meanings that led it to be shared and to flourish in others' imaginations.

This is the main difference between "beings of fictions" and "beings of reference", the latter associated with science. While science is built on the same raw materials, and is as imaginative as art, there are limits to where it leads its audience, a type of discipline that makes scientific artifacts tell a more controllable and traceable story. In the author's words, "The sciences may be fictions, but they are domesticated enough to report, refer, inform". (LATOUR, 2013, p. 252). Taking this argument into consideration, a verifiable narrative has a dif- 
ferent nature when compared to a problematic information. Considering such distinctions, where can the Diário do Brasil article be situated?

By tracking that article, I could realize that its origin in a long pathway was an investigation leaked from the Brazilian Federal Police. An anonymous source from the police shared information with at least one journalist on the apparent sudden interest in the airplane model that crashed in a public repository of airplanes photos online weeks before the accident. The journalist responsible for the "scoop" reported by the Diário do Brasil is an established and awardwinning professional. He used to write on Yahoo! Notícias (Yahoo News), and other prestigious outlets, and is also a university professor at a traditional institution. With that privileged information in hand, the journalist recorded a one-minute video while in a restaurant, showing the airplane database picture on his cellphone and explaining the case as an ongoing investigation. He then posted the video on his channel on YouTube, which is not available anymore at the time of writing, with the title "Federal Police investigates if Teori's airplane was being followed" (emphasis added).

Notably, the hypothesis in that report became a thesis: the Diário do Brasil changed if to that. Additionally, the verb (apura) that precedes it has a double meaning in Portuguese, and can also mean "find out"-, the meaning that was prioritized in the Diário do Brasil title. ${ }^{5}$ Furthermore, the public photo repository became the manufacturer's database in this fabricated version. Here, a new story was born to be shared thousands of times, while the original piece was also circulating, to the delight of the journalist who celebrated on Twitter more than 122 thousand views "in a day", receiving compliments in the comments. (TOGNOLLI, 2017)

Clearly, the business model based on the monetization of views and clicks, the sense of opportunity showed by the relevance algorithms, the political context of a nation under a traumatic schism, the social network dynamics in the private and public spheres, among others, played a role in the informal communication of the journalist in his own Twitter and YouTube channels, as well as the subsequent reformulation of its content on a website that projected itself as a news outlet. Diário do Brasil, which had at that time thousands of followers on Facebook, still has a domain and a website online, but its Facebook webpage could not be found in 2020 .

5 Original title: "Urgente: Polícia Federal apura que o avião em que o ministro Teori Zavascki embarcou era seguido há 16 dias". Later, this title was changed to be even more emphatic: "Plane that Minister Teori Zavascki boarded was followed for 16 days" ("Avião em que ministro Teori Zavascki embarcou foi seguido durante 16 dias"). 
In 2018, an electoral year in Brazil, Facebook excluded almost two hundred pages associated with the spread of disinformation online; however, the company did not inform which pages were excluded. (FACEBOOK..., 2018) While it is not possible to know if the deletion of Diário do Brasil from Facebook happened as a result of such a policy, the lack of public information on the matter shows how these digital platforms work under their own rules, in a privatized mode, benefiting from the ambiguous term "platforms" so as to not be framed (and regulated) as media outlets. (GILLESPIE, 2010) Nevertheless, as this paper shows, all the digital platforms that emerged in the case: Facebook (including its WhatsApp and YouTube), Google, and Twitter are part of the actor-network that is found to be involved in the conspiracy theory regarding the death of the Justice Teori Zavascki. Furthermore, they are co-responsible for these communication processes and the spread of content that makes conspiracy theories take form. "The platforms do not create speeches, but have algorithmic systems that distribute the speeches [...]". (SILVEIRA, 2018, p. 37) This shows the technopolitics of communication in times of digital platforms, whose private attributes and intellectual property protections contribute for us, as a society, to still be at the very beginning of understanding how social media algorithms work.

\section{FINAL CONSIDERATIONS}

For Carey, journalism is a symbolic system that allows society to "create, express, and convey [...] knowledge of and attitudes toward reality" (CAREY, 2009, p. 24) as religion, common sense, art, and mythology also do. In this sense, "reality is brought into existence, is produced, by communication - by, in short, the construction, apprehension, and utilization of symbolic forms". (CAREY, 2009, p. 22) What the present paper adds to this perspective is how this symbolic system is materially built within a network of relations. People give meaning to what is read, through processes that are socially built and historically situated. (CAREY, 2009) Nevertheless, as they are part of a network - with other individuals, artifacts, corporations, etc. -, action is distributed, as are the meanings that are in constant configuration. Considering that the sharing of unverified or problematic information, so-called "fake news," works as a bond between members of likeminded groups on one side, and as a source of user engagement and profit for content producers and intermediaries on the other, it is necessary to recognize the participation and co-responsibility of all members involved in this complex and distributed communication process. The opposi- 
tion between "real" and "fake" is too limited to make sense of how conspiracy theories spread digitally, given that such terms do not account for the technopolitics of the phenomenon.

\section{ACKNOWLEDGEMENTS}

The author would like to thank the reviewers for their thoughtful comments and suggestions to improve the article. The author is also deeply grateful to her stirring friends for the inspiring conversations and their consent for this work to be published.

\section{REFERENCES}

BALLOUSSIER, A. V. Morte de Teori Zavascki alimenta teorias da conspiração. Folha de S.Paulo, São Paulo, 19 jan. 2017. Disponível em: http://www1.folha.uol.com.br/ poder/2017/01/1851293-morte-de-teori-zavascki-alimenta-teorias-da-conspiracao-nainternet.shtml. Acesso em: 22 jan. 2021.

BRASIL. Senado Federal. CEI2016: Comissão Especial do Impeachment 2016: Atividade Legislativa. Brasília, DF: Senado Federal, 2016. Disponível em: https://legis.senado.leg. $\mathrm{br} /$ comissoes/comissao?o\&codcol=2016. Acesso em: 22 jan. 2021.

BRIGIDO, C. Equipe de Teori no STF não tirou férias para analisar delação da Odebrecht. O Globo, Rio de Janeiro, 13 jan. 2017. Disponível em: https://oglobo.globo. $\mathrm{com} /$ brasil/equipe-de-teori-no-stf-nao-tirou-ferias-para-analisar-delacao-daodebrecht-20768341. Acesso em: 22 jan. 2021.

BRUNO, F. Rastros digitais sob a perspectiva da teoria ator-rede. Revista Famecos, v. 19, n. 3, p. 681-704, 2012.

CAREY, J. W. A Cultural Approach to Communication. In: CAREY, J. W. Communication as Culture: Essays on Media and Society. Revised edition. New York: Routledge, 2009. p. 11-28.

CARVALHO, P. M. Avião em que ministro Teori Zavascki embarcou foi seguido durante 16 dias. Diário do Brasil, Mauá, 20 jan. 2017. Disponível em: https://diariodobrasil. org/urgente-pf-apura-que-aviao-em-que-ministro-teori-zavascki-embarcou-eraseguido-ha-16-dias/. Acesso em: 22 jan. 2021.

CLARK, L. S.; MARCHI, R. M. Young people and the future of news: social media and the rise of connective journalism. New York: Cambridge University Press, 2017.

COLON, L. Delator da Odebrecht cita Temer, Renan, Maia e mais de 20 políticos. Folha de S.Paulo, São Paulo, 9 dez. 2016. Disponível em: http://www1.folha.uol.com.br/ 
poder/2016/12/1840131-odebrecht-levou-dinheiro-a-escritorio-de-amigo-de-temerdiz-delator.shtml. Acesso em: 22 jan. 2021.

CUENCA, J. P. Previsões para 2017: Mãe Aleksandra conta tudo. The Intercept Brasil, Rio de Janeiro, 5 jan. 2017. Disponível em: https://theintercept.com/2017/01/05/previsoespara-2017-mae-aleksandra-conta-tudo/. Acesso em: 22 jan. 2021.

EMPOLI, G. Os engenheiros do caos: como as fake news, as teorias da conspiração e os algoritmos estão sendo utilizados para disseminar ódio, medo e influenciar eleições. São Paulo: Vestígio, 2019.

FACEBOOK remove 196 páginas do Brasil sob acusação de "desinformação". Veja, São Paulo, 25 jul. 2018. Disponível em: https://veja.abril.com.br/brasil/facebook-retira-doar-196-paginas-sob-acusacao-de-fake-news. Acesso em: 22 jan. 2021.

FREELON, D. Discourse Architecture, Ideology, and Democratic Norms in Online Political Discussion. New Media \& Society, Thousand Oaks, v. 17, n. 5, p. 772-791, 2015.

GASPARI, E. Não é teoria da conspiração, é dúvida. Folha de S. Paulo, São Paulo, 21 jan. 2017. Disponível em: http://www1.folha.uol.com.br/colunas/ eliogaspari/2017/01/1852018-nao-e-teoria-da-conspiracao-e-duvida.shtml. Acesso em: 22 jan. 2021.

GILLESPIE, T. The Politics of "Platforms". New Media $\&$ Society, Thousand Oaks, v. 12, n. 3, p. 347-364, 2010.

GREENWALD, G. Small-plane crash that killed brazil's key corruption judge demands investigation and protection from Temer. The Intercept Brasil, Rio de Janeiro, 20 jan. 2017. Disponível em: https:/theintercept.com/2017/01/20/small-plane-crash-thatkilled-brazils-key-corruption-judge-demands-investigation-and-protection-fromtemer/. Acesso em: 22 jan. 2021.

HABERMAS, J. The public sphere: an encyclopedia article (1964). New German Critique, Ann Arbor, n. 3, p. 49-55, 1974.

HALL, S. Encoding/decoding. In: DURHAM, M. G.; KELLNER, D. M. (ed.). Media and Cultural Studies: keyworks. Revised edition. Malden: Blackwell Publishing, 2006. p. 163173.

HOWARD, P. N. Lie Machines: How to Save Democracy from Troll Armies, Deceitful Robots, Junk News Operations, and Political Operatives. New Haven: Yale University Press, 2020.

JACK, C. Lexicon of Lies: Terms for Problematic Information. Data \& Society, New York, ago. 2017. Disponível em: https://datasociety.net/wp-content/uploads/2017/08/ DataAndSociety_LexiconofLies.pdf. Acesso em: 22 jan. 2021.

LATOUR, B. An Inquiry Into Modes of Existence: an Anthropology of the Moderns. Cambridge, MA: Harvard University Press, 2013. 
LATOUR, B. Pandora's Hope: Essays on the Reality of Science Studies. Cambridge, MA: Harvard University Press, 1999.

LATOUR, B. Reassembling the Social: an Introduction to Actor-network-theory. Oxford; New York: Oxford University Press, 2005.

MACHADO, D. A modulação de comportamento nas plataformas de mídias sociais. In: SOUZA, J.; AVELINO, R.; SILVEIRA, S. A. (ed.). A sociedade de controle: manipulação e modulação nas redes digitais. São Paulo: Hedra, 2018. p. 47-69.

NISSENBAUM, H. Privacy in context: technology, policy, and the integrity of social life. Stanford, CA: Stanford Law Books, 2010.

PAND. Photo ID 8227524. JetPhotos, [s. 1.], 21 mar. 2016. Disponível em: https://www. jetphotos.com/photohistory.php?id=8227524\&range=30. Acesso em: 22 jan. 2021.

PHILLIPS, D. Brazil senate approves austerity package to freeze social spending for 20 years. The Guardian, London, 13 dez. 2016. Disponível em: http://www.theguardian.com/ world/2016/dec/13/brazil-approves-social-spending-freeze-austerity-package. Acesso em: 22 jan. 2021.

PIVA, A. How the Zavascki plane crash could advance a political agenda in Brazil. Council on Hemispheric Affairs, Washington, DC, 31 jan. 2017. Disponível em: https:// www.coha.org/how-the-zavascki-plane-crash-could-advance-a-political-agenda-inbrazil/. Acesso em: 22 jan. 2021.

ROSA, F. R.; DIAS, M. C. N. Letramento digital: significados existentes e a proposição de um conceito. In: PEREIRA NETO, A.; FLYNN, M. B. (org.). Internet e saúde no Brasil: desafios e tendências. São Paulo: Cultura Acadêmica, 2021.

SCHEUFELE, D. A. Framing as a theory of media effects. Journal of Communication, Hoboken, v. 49, n. 1, p. 103-122, 1999.

SHIRKY, C. Here comes everybody: the power of organizing without organizations. New York: Penguin Books, 2008.

SILVEIRA, S. A. A noção de modulação e os sistemas algorítmicos. In: SOUZA, J.; AVELINO, R.; SILVEIRA, S. A. (ed.). A sociedade de controle: manipulação e modulação nas redes digitais. São Paulo: Hedra, 2018. p. 31-46.

SUSTEIN, C. R. The daily we: is the internet really a blessing for democracy? Boston Review, Cambidgre, MA, v. 26, n. 3, 2001.

THE EDGE of democracy. Direção de Petra Costa. Brasil: Netflix, 2019. (121 min.).

TOGNOLLI, C. 122 mil em um dia: obrigado!!!! [S. 1.], 21 jan. 2017. Twitter: @ claudiotognolli. Disponível em: https://twitter.com/claudiotognolli/ status/822936814084354048. Acesso em: 22 jan. 2021.

WATTS, J. Brazil supreme court justice overseeing vast corruption case dies in plane crash. The Guardian, London, 19 jan. 2017. Disponível em: http://www.theguardian. 